\title{
The Irrelevance of the Application of the Principle of Opportunity by the Attorney General and the Principle of Equality before the Law
}

\author{
Kharisma Ramadhan * \\ DOI: https://doi.org/10.22304/piih.v5n2.a4
}

Submitted: January 22, 2018 | Accepted: August 31, 2018

\begin{abstract}
In the Indonesian criminal justice system, dismissal of cases for the good of public interest is a manifestation of the principle of opportunity as set forth in Article 35(c) of Law Number 16 of 2004 on Indonesian Attorney. The application of the principle of opportunity is deemed to contradict the principle of equality before the law, which is introduced in the Indonesian Constitution, because it creates discrimination in the process of law enforcement. The absence of a comprehensive legislation policy on the application of the principle of opportunity in the Indonesian criminal justice system has led to contradictions. It weakens the principle of equality before the law, which has been guaranteed by the constitution. In addition, it can cause constitutional harm to a number of citizens. Nevertheless, the existence of the principle of opportunity remains recognized in the Indonesian criminal justice system because, in principle, it contains the values of goodness to balance the sharp principles of legality. This writing aims to analyze and to understand the legislation policy on the application of the principle of opportunity. It also reveals the meaning of abstraction and multiple interpretations of public interest, the influence of the application of the principle of opportunity to the principle of equality before the law, and the relevance of the application of the principle of equality and the principle of equality before the law.
\end{abstract}

Keywords: dismissal of case, equality before the law, principle of opportunity.

\section{Irelevansi Penerapan Asas Oportunitas oleh Jaksa Agung dengan Asas Persamaan Kedudukan di Hadapan Hukum}

\begin{abstract}
Abstrak
Dalam sistem peradilan pidana Indonesia, pengesampingan perkara demi kepentingan umum merupakan perwujudan dari asas oportunitas yang dituangkan dalam ketentuan pasal 35(c) UU No. 16 Tahun 2004 Tentang Kejaksaan RI. Penerapan asas oportunitas tersebut dianggap bertentangan dengan asas persamaan kedudukan di hadapan hukum yang telah diintrodusir dalam Konstitusi negara Indonesia karena menimbulkan diskriminasi dalam proses penegakan hukum. Tidak adanya kebijakan legislasi yang komprehensif tentang penerapan asas oportunitas dalam sistem peradilan pidana Indonesia menyebabkan pertentangan yang justru melemahkan asas persamaan kedudukan di hadapan hukum yang telah dijamin oleh konstitusi dan dapat menyebabkan kerugian konstitusional terhadap sebagiian warga negara. Meskipun demikian keberadaan asas oportunitas tetap diakui dalam sistem peradilan pidana Indonesia, karena pada prinsipnya mengandung nilai-

PADJADJARAN Journal of Law Volume 5 Number 2 Year 2018 [ISSN 2460-1543] [e-ISSN 2442-9325]

* A Graduate School Student of Parahyangan Catholic University in the Study Program of Law, Jl. Merdeka No. 30, Bandung, cacienk13@gmail.com, S.H. (Universitas Katolik Pahrayangan).
\end{abstract}


nilai kebaikan untuk mengimbangi tajamnya asas legalitas. Penulisan ini bertujuan untuk menganalisis dan memahami tentang kebijakan legislasi penerapan asas oportunitas juga terkait makna kepentingan umum yang bersifat abtrak dan multitafsir, pengaruh penerapan asas oportunitas terhadap asas persamaan kedudukan di hadapan hukum, serta relevansi penerapan asas oportunitas dengan asas persamaan kedudukan di hadapan hukum.

Kata kunci: asas legalitas, deponering/seponering, persamaan kedudukan di hadapan hukum.

\section{A. Introduction}

The prosecution stage of criminal cases in several countries, either that apply the common law system and the civil law system, recognizes two principles of prosecution that are valid, but have different meanings and are contradictory. They are the principles of legality and opportunity. The principle of legality in formal criminal code is not the principle of legality as referred to in the material criminal code. In the material criminal code, the principle of legality means that an act cannot be punished except for the power of the criminal code in the preexisting legislation. The principle of legality in material criminal law is famous for the legendary admonition Von Feuerbach, which reads nullum delictum nulla poena sine praevia lege poenali. On the other hand, the principle of legality in formal criminal law means that an attorney, as the public prosecutor, is obliged to prosecute a suspect who is alleged to have committed a criminal act and the case file has fulfilled formal and material requirements, without exception. Meanwhile, according to the principle of opportunity, a public prosecutor is not obliged to prosecute someone who commits a crime if, according to consideration, the prosecution may harm public interest. ${ }^{1}$ The principle of opportunity is a principle that provides an opportunity for public prosecutor not to prosecute a criminal case in a condition where the prosecution cannot be carried out, or the prosecution may harm the public interest or the government. In some countries, the impact of individual interests even must be taken into account before ruling out the case. Andi Hamzah says, globally and internationally, the principle of opportunity can be interpreted as the decision of public prosecutor, conditionally or unconditionally, to make or not to make a prosecution. The public prosecutor can decide, either on conditions or without conditions, to prosecute or not to prosecute in court. ${ }^{2}$

In the prosecution stage of a criminal case, an attorney is an official who is authorized by law to act as a public prosecutor and to prosecute criminal cases in accordance with Law Number 8 of 1981 on Criminal Procedure Law (KUHAP). There is no other bodies or officials who can carry out the authorities. Therefore, prosecution authority becomes a monopoly of attorney as the public prosecutor (dominus litis). ${ }^{3}$ An attorney who holds prosecution authority has the obligation to

Djoko Prakoso, Eksistensi Jaksa Ditengah-tengah Masyarakat, Jakarta: Ghalia Indonesia, 1985, p. 29.

Constitutional Court, Minutes of Case Session Number 29/PUU-XIV/2016, p. 10.

See Article 13-15 Law Number 8 of 1981 on Criminal Procedure Code (KUHAP). 
transfer criminal cases to a court with a request to adjudicate the case accompanied by an indictment immediately. ${ }^{4}$ It is in the condition when the Prosecutor is of the opinion that the investigation can carry out the prosecution and there is no reason to terminate the prosecution. ${ }^{5}$ The public prosecutor is obliged to bring a case in order to prosecute it before a judge. In this context, the principle of legality in formal criminal law is applied.

In addition to adhering the principle of legality, Indonesia also recognizes the existence of the principle of opportunity in the criminal justice system. This can be seen in the elucidation of Article 77 of the Criminal Procedure Code, which states "yang dimaksud dengan penghentian penuntutan tidak termasuk penyampingan perkara untuk kepentingan umum yang menjadi wewenang Jaksa Agung" (the termination of prosecution does not include the provision of case for the public interest, which is the authority of the Attorney General). The elucidation of Article 77 of the Criminal Procedure Code explains that in the Indonesian criminal justice system, the Attorney General has an authority to override cases for the public interest. Then the authority is regulated in a law, the last of which is the provisions of Article 35(c) of Law Number 16 of 2004 on the Attorney General of the Republic of Indonesia (Prosecutor's Law), which states that "Jaksa Agung mempunyai tugas dan wewenang', diantaranya adalah 'mengesampingkan perkara demi kepentingan umum" (The Attorney General has the duty and the authority that includes putting aside cases for the public interest).

In the Indonesian criminal justice system, the authority to implement the principle of opportunity based on the provisions of Article 35 (c) of the Prosecutor's Law or known as the dismissal of cases for the public interest (Indonesian Law Term: seponering/deponering $)^{6}$ is an authority that is only possessed by the Attorney General. In its implementation, it requires "for the public interest". In the elucidation of Article 35 (c) of the Prosecutor's Law, the term 'public interest' is defined as 'the interests of the nation and the state and/or the interests of the wider community'. The problem then is the explanation of the term 'public interest' in the Prosecutor's Law, which is ambiguous. In short, it does not provide clear and 4 See Article 143 of Criminal Procedure Code.

5 See Article 140 of Criminal Procedure Code. There are three conditions that can cause the public prosecutor to make a decision not to prosecute for technical reasons, namely if there is not enough evidence; the event is not a criminal act; the case is closed by law (Closed "by law" includes, among others, the suspect died, ne bis in idem, and the merger of the suspect's case with the case that has been submitted to court previously).

6 In putting aside the case for the public interest, the more appropriate term to use is actually seponering. Even so, now practitioners use the term deponering more often. This is quite reasonable because in the DutchIndonesian legal term dictionary, the word deponering is interpreted with an equivalent interpretation of seponering. In some Dutch-Indonesian legal dictionaries, deponeren can be interpreted as registering, entrusting, storing, setting aside, negating, placing for review, ruling out cases, ruling out criminal charges by the public prosecutor. Seponeren means to override, to call down, to be used in criminal cases in the sense of leaving aside, no prosecution by the public prosecutor based on the principle of opportunity, or because the evidence is not complete enough to make a lawsuit.

Hukum Online, "Bahasa Hukum: Seponering atau Deponering?Kamus bahasa Belanda - Indonesia mengenal kata 'deponeren' dan 'seponeren', http://www.hukumonline.com/berita/baca/lt4cecd0c51fb6b/bahasahukum-iseponeringi-atau-ideponeringi, accessed on April 2018. 
criteria and limitations on what is meant by 'the interests of the nation and the state and/or the interests of the wider community'. Therefore, the interpretation of 'the interests of the nation and state and/or the interests of the wider community' can be interpreted subjectively and differently depending on the perspective of interpreter. The absence of clear and firm criteria, parameters, benchmarks, or limitations on the term 'public interest', which is a formal requirement in implementing the principle of opportunity, can lead to violations of a person's rights, because there is no legal certainty in the meaning of the term.

Article 1, Paragraph (3) of the 1945 Constitution (UUD 1945) mentions that Indonesia is a legal state. Consequently, Indonesia must fulfill the elements of a legal state. One of the elements of a legal state is the recognition of human rights and the equality before the law. The recognition of equality before the law can be found in the Indonesian constitution, namely in Article 27 Paragraph (1) of the 1945 Constitution, which reads "Segala warga negara bersamaan kedudukannya di dalam hukum dan pemerintahan wajib menjunjung tinggi hukum dan pemerintahan itu dengan tidak ada kecualinya" (All citizens are equal before the law and the government with no exception). Likewise, Article 28D of the 1945 Constitution states that "Setiap orang berhak atas pengakuan, jaminan, perlindungan, dan kepastian hukum yang adil serta perlakukan yang sama di hadapan hukum" (Every person has the right to the recognition, guarantee, protection, and fair legal certainty and equal treatment before the law). The equality before the law as stated in Article 27 (1) and Article 28D of the 1945 Constitution aims to uphold justice, where equality means the law as an entity does not distinguish anyone who asks for justice. This provision has the meaning that every Indonesian citizen, regardless native or non-native, educated or not educated, the upper or the lower class, must be treated equal before law. This principle provides protection for the human rights of citizens and must be realized by the government or law enforcement. Thus, the principle of equality before the law must be a buffer in the building of the rule of law, which positions the law as the supreme entity in the life of the nation and the state. Each individual is equal before law regardless of social status because the concept of equality before the law has been embedded in the constitution as the highest recognition in the system of legislation. ${ }^{7}$

When the concept of equality before the law is related to the principle of prosecution in criminal procedural law, namely the principles of legality and opportunity, the principle of legality is the realization of the principle of equality before the law. It is because the principle of legality requires the same thing with the principle of equality before the law, that every person suspected of committing a crime should be treated equally before the law. In this case, the prosecution is carried out in court to be examined and tried, or in other words that as long as there are no reasons for the prosecution to be terminated, the public prosecutor is

Eka N.A.M Sihombing, "Mendorong Pembentukan Peraturan Daerah Tentang Bantuan Hukum Di Provinsi Sumatera Utara”, Jurnal Rechtsvinding Media Pembinaan Hukum Nasional, Vol. 2, No. 1, 2013, p. 83. 
obliged to hand over the case for prosecution before the judge. On the other hand, the principle of opportunity in the Indonesian criminal justice system seems to have given rise to the notion that there is inconsistency, contradiction, and 'dualism' towards the principle of equality the law. On the one side, it recognizes and affirms that everyone has a same right the law. On the other side, the recognition is excluded by the existence of the principle of opportunity. It seems to give privileges to certain people with the reason for the public interest so that there is no prosecution before the court to be tried and examined, despite formal and material conditions of the prosecution has been fulfilled. ${ }^{8}$

Based on the description, the application of the principle of opportunity by the Attorney General in dismissal of a case for the public interest, from the perspective of the principle of equality before the law, should be studied and examined. It is especially by considering that the Attorney General has formal requirements "for the public interest", which is interpreted in the elucidation of the Prosecutor's Law as "the interests of the nation and the state and/or the interests of the wider community". It is can have multiple interpretations and do not have clear criteria and limitations, thus causing prone legal uncertainty against abuse of authority. In addition, the Attorney General's authority in applying the principle of opportunity is deemed to conflict and even contradicts the principle of equality before the law.

This study is limited discussion into several problems. Firstly, how is the legislation policy on the application of the principle of opportunity based on the provisions of Article 35 (c) of the Prosecutor's Law and the effect of applying the principle of opportunity to the principle of equality before the law in the Indonesian criminal justice system. Secondly, is it still relevant to the implementation of the principle of opportunity based on the provisions of Article 35 (c) of the Prosecutor's Law in the Indonesian criminal justice system.

\section{B. Legislation Policy Regarding the Application of Opportunity Principle based on the Provisions of Article 35(c) of Law Number 16 of 2004 on the Attorney's Office of the Republic of Indonesia}

The principle of opportunity is considered as the opposite of the principle of legality. It is understood as a principle that gives discretion to the public prosecutor not to prosecute. The discretion does not take into account even though there is sufficient evidence in a criminal act, and the clarity as to who the perpetrator is, and there is no requirement for the dismissal of case, with consideration if prosecution is still being carried out so the public interest will be greatly harmed. ${ }^{9}$ In other words, the

\footnotetext{
See M. Yahya Harahap, Pembahasan Permasalahan dan Penerapan KUHAP, Penyidikan dan Penuntutan, $2^{\text {nd }}$ edition, Sinar Grafika, Jakarta, 2003, p. 36 .

9 Subekti and R. Tjitrosoedibjo, Kamus Hukum, Jakarta: Pradnya Paramita, 1978, p. 88. See Peter J.p. Tak, "The Dutch Prosecutor: A Prosecuting and Sentencing Officer" in Erik Luna and Marianne Wade (eds.), The Prosecutor in Transnational Perspective, Oxford: Oxford University Press, 2012, p. 145, and Mohammad Taufik Makarao dan Suhasril, Hukum Acara Pidana Dalam Teori dan Praktik, Jakarta: Ghalia Indonesia, 2004, p. 3.
} 
dismissal of case is carried out on case that is clearly evidenced, ${ }^{10}$ a case where the results of the investigation are complete and fulfilled for submission to the court, ${ }^{11}$ but no prosecution is made for public interest.

The Criminal Procedure Code at a glance 'seems' not adhered to the principle of opportunity. It adheres to the principle of legality alone. This can be confirmed in the Article 140(2)(a):

Dalam hal penuntut umum memutuskan untuk menghentikan penuntutan karena tidak terdapat cukup bukti atau peristiwa tersebut ternyata bukan merupakan tindak pidana atau perkara ditutup demi hukum, penuntut umum menuangkan hal tersebut dalam surat ketetapan

[In the event that the public prosecutor decides to stop the prosecution because there is no enough evidence or the incident turned out not to be a criminal act or the case is closed by law, the public prosecutor has stated this matter in a decree]

The implicit meaning contained in the article holds that the public prosecutor must sue all cases that have fulfilled the conditions determined by law before the court, unless there is no evidence, or the incident is not a criminal act, or the case is closed for the sake of law. The meaning of the article must be interpreted alternatively. This is in accordance Article 14 (h) of the Criminal Procedure Code, that a public prosecutor is given the authority to close the case only for the sake of the law, not for the public interest. Thus, we can see clearly that the Criminal Procedure Code adheres to the principle of legality because it requires that all criminal cases that have met the requirements for prosecution, the prosecutor is obliged to prosecute before the court.

In spite of the above, when we review the provisions of the Criminal Procedure Code carefully and deeply, there is a distinction between the authorities possessed by the public prosecutor to terminate prosecution with the authority possessed by the Attorney General to override cases for the public interest. The provisions in the Criminal Procedure Code that regulate the differentiation can be observed in the elucidation of Article 77 of the Criminal Procedure Code. It reads "yang dimaksud dengan penghentian penuntutan tidak termasuk penyampingan perkara untuk kepentingan umum yang menjadi wewenang Jaksa Agung" (what is meant by termination of prosecution does not include the dismissal of cases for the public interest which is the authority of the Attorney General). Thus, the elucidation in Article 77 of the Criminal Procedure Code actually has explained sufficiently the authority possessed by the Attorney General in overriding a case for the public interest. Therefore, it can be concluded that the Criminal Procedure Code recognizes the existence of the principle of opportunity. Consequently,

$10 \quad$ R. Wirjono Prodjodikoro, Hukum Acara Pidana di Indonesia, Bandung: Sumur Bandung, 1990, p. 28.

11 H.M.A. Kuffal, Penerapan KUHAP dalam Praktik Hukum, Malang: UMM Press, 2005, p. 218. 
the realization of the principle of opportunity in the Criminal Procedure Code no longer needs to be disputed. ${ }^{12}$ In addition the Criminal Procedure Code, the regulation regarding the principle of opportunity in the Indonesian criminal justice system is set forth in the provisions of Article 35(c) of the Prosecutor's Law, which states that the Attorney General has duties and authorities, including, "mengesampingkan perkara demi kepentingan umum" (to dismiss a case for the public interest).

Theoretically, there are two views on the principle of opportunity, namely positive and negative. According to the positive view, a prosecution can only be done if formal conditions are met and it must also be deemed necessary for the public interest. Therefore, a public prosecutor will not sue a case before the element of public interest can be fulfilled, namely whether a prosecution is true really desired by the public interest or not. ${ }^{13} \mathrm{~A}$ country that adopts this positive view is the Netherlands. On the other hand, according to the negative view, the application must always be a privilege (uitzondering) to the general obligation to prosecute any criminal offense. Therefore, the emphasis is on the prosecution of every criminal offense that is absolute but, in matters that are based on public interest, there may be deviations from the principle. ${ }^{14}$

In this case, Indonesia adheres to the negative view on the principle of opportunity. A public prosecutor in principle has an obligation to prosecute, unless there are things that are opposed to the prosecution. It can be said also that the prosecutor must prosecute and a dismissal of a case is an exception. This is reflected in Article 139 of the Criminal Procedure Code, which affirms that after the public prosecutor receives or accepts the results of a complete investigation from the investigator, the prosecutor determines immediately whether the case file has fulfilled the requirements to be transferred to court. Nonetheless, in the event that a Public Prosecutor does not prosecute or does not hand over the case file to court, the Criminal Procedure Code only limits the technical provisions, such as no enough evidences, the incident not a criminal act or the case is closed by law. It is stated in Article 140 (2) (a), which is theoretically referred to as the termination of prosecution. The exemption from technical reasons is the reason for the policies stipulated in the provisions of Article 35(c) of the Prosecutor's Law, regarding the duties and authority of the Attorney General to dismiss a case for the public interest. The application has a formal requirement "for the public interest" and the prosecutor must seek advices from other related state authority bodies first. Then, a prosecution is an obligation while dismissal of a case for the public interest is an exception.

12 Departemen Kehakiman Republik Indonesia [Ministry of Justice of the Republic of Indonesia], Pedoman Pelaksanaan Kitab Undang-undang Hukum Acara Pidana, $3^{\text {rd }}$ edition, Jakarta: Yayasan Pengayoman, 1983, p. 88.

13 A. Karim Nasution, "Kepentingan Umum Sebagai Dasar Penyampingan Perkara", this paper is presented at Symposium on Principle of Opportunity Issues, Ujung Pandang November 4-5, 1981, p. 57.

14 Ibid. 
The implementation of the principle of opportunity based on the provisions of Article 35(c) of the Prosecutor's Law states a formal requirement "for the public interest", an abstract term that is easily understood theoretically but when it enters into the level of implementation will become complicated. It can even cause quite complex problems. The Prosecutor's Law does not provide clear criteria, benchmarks, or parameters about what is meant by 'public interest'. In the elucidation of Article 35(c), the Prosecutor's Law only provides an elucidation that public interest is "the interests of the nation and state and/or the interests of the wider community". It also states that "Mengesampingkan perkara sebagaimana dimaksud dalam ketentuan ini merupakan pelaksanaan asas oportunitas, yang hanya dapat dilakukan oleh Jaksa Agung setelah memperhatikan saran dan pendapat dari badan-badan kekuasaan negara yang mempunyai hubungan dengan masalah tersebut" (to dismiss a case for the public interest as referred to in this provision is the implementation of the principle of opportunity, which only can be carried out by the Attorney General after paying attention to the advices and the opinions of state power bodies that is correlated to the problem).

The use of the term 'public interest' is very diverse, ranging from what we normally use everyday, which is used commonly by legal experts, as well as those written in the legislation. Sjachran Basah says that the term 'public interest' (including its criteria) is a term that is elastic and stretchy, because it can be interpreted in various ways depending on the circumstances and points of view. The formulation of 'the public interest' itself is difficult because the many problems are contained so that it needs to be stipulated by the Law. ${ }^{15}$ Sjachran Basah thought which states that the term 'public interest' is a term that is stretchy is very reasonable because the term 'public interest' is a multi-interpretive phrase that can cause clashes of various values. It is very difficult to determine criteria and clear and limited measurement. Without an adequate interpretation of the meaning of term 'public interest' or 'for the public interest', it can lead to potential constitutional losses by some citizens.

The absence of adequate further elucidation of what is meant by "the interests of the nation and the state and/or the interests of the wider community" which is an explanation of the phrase "public interest" is the main issue in the implementation of the principle of opportunity under the provisions of Article 35(c) of the Prosecutor's Law. In the absence of further explanation to determine limits, criteria, or parameters of "the interests of the nation and state and/or the interests of the wider community", the Attorney General has an authority to determine whether or not there is a "public interest" as a condition for dismissal of a case and to interpret the meaning broadly and subjectively.

Sjachran Basah, “Permasalahan Arti Kepentingan Umum”, Pro Justitia - Faculty of Law Parahyangan University Magazine, June 1983, p. 73. 
Thus, the explanation of the term 'public interest', which is interpreted as "the interests of the nation and the state and/or the interests of the wider community", based on the principles of the formation of laws and regulations, does not reflect the principle of lex certa ${ }^{16}$ in its formation. It is because the term 'public interest' is multi-interpretative. The meaning of "public interest" depends very much on the point of view of the interpreter.

Afterward, related to the procedures and mechanism for implementing the principle of opportunity, this study has not found the legal basis used by the Attorney General as a guideline, procedure, and mechanism for implementing the principle of opportunity, either in the forms of Laws, Government Regulation in Lieu of Law, Government Regulation, and Ministerial Decree. The procedure or mechanism for dismissal of a case is a very fundamental matter because the implementation of the principle of opportunity by putting aside a criminal case for the public interest is an extraordinary law enforcement process. It deviates from criminal procedural law procedures that should run in a coherent, tiered, and continuous manner but is stopped when it arrived at the stage of investigation.

The provisions of Article 35(c) of the Prosecutor's Law have freely given the Attorney General the authority to dismiss cases for the public interest (Indonesian term: deponering/seponering) based on the discretion or freies ermessen owned by the Attorney General. Nevertheless, in carrying out its discretion to dismiss a case for the public interest, the Attorney General must have, or give, a rational or reasonable reason. It is absolute and must be done so as not to be arbitrary. ${ }^{17}$

Abuse of authority or being arbitrary, in general is closely related to discretionary authority. D.J. Galligan in his book 'Discretionary Power' states that being arbitrary or arbitrariness is related to giving reasons in the decision-making process and is considered as the antithesis of reasonable actions so that rationality is a fundamental requirement in any decision-making, especially based on discretion. ${ }^{18}$ In general, arbitrary concept is called unreasonable action. Because arbitrary concept is closely related to common sense considerations, arbitrary elements can be tested with the principle of rationality or appropriateness. An action is categorized as containing arbitrary elements, if the action is clearly unreasonable or irrational. ${ }^{19}$

Since rationality is a fundamental requirement in every decision making, especially that is based on discretion, then it is also a basic requirement in making decisions or policies for the Attorney General to dismiss a case for the public interest, as long as the implementation is still based on the provisions of Article 35(c) of the Prosecutor's Law. Therefore, if the Attorney General without rational or reasonable foundation carries out a dismissal of a case for the public interest,

16 Lex certa can be interpreted that the rule of law must be clear and not cause multi-interpretation, or the legislation policy in formulating the law must be complete and clear without vague (Nullum Crimen Sine Lege Stricta) in order to realize legal certainty.

17 See explanation by Gede Pantja Astawa in Constitutional Court Case Number 29/PUU-XIV/2016.

18 Ibid.

19 Ibid. 
then it can be considered an abuse of authority. It has denied the right for the recognition, guarantee, protection, and fair legal certainty as well as equality before the law. It is a discriminatory treatment against the interest of victim who have been marginalized and the privilege is granted to the alleged perpetrator of crime whose case is ruled out. However, the focus of how is the rationality tested, who is testing it, and what is the testing procedure will certainly be further problems if there is no legal institution that tests the rationality of a decision to dismiss a case for the public interest.

\section{Exploring the Meaning for Public Interest}

To find the meaning of "public interest" or "for the public interest", this study used the legal discovery approach by the method of interpretation or elucidation of the law. Interpretation or elucidation of law is a method of legal discovery that provides clear and sharp explanations of the texts of the laws. Therefore, the scope of the law can be applied in certain legal events. ${ }^{20}$ Of the many methods of interpretation or elucidation of existing laws, this study only uses three methods of interpretation or elucidation of the law: grammatical, systematic, and historical methods to find the meaning of "public interest" or "in the public interest"

First, grammatical interpretation is to interpret words or terms in legislation in accordance with the language of the applicable laws. This grammatical interpretation tries to understand a text of prevailing laws and regulations. In general, grammatical interpretation is used by judges together with logical interpretations, namely giving meaning to a rule of law through legal reasoning to be applied to obscure or ambiguous texts. ${ }^{21}$ Second, systematic interpretation is a method of interpreting legislation by relating it to other legal regulations or to the whole legal system. This systematic interpretation applies the principle that the legislation of a country is a complete system. Interpretation of a statutory provision must be linked to the provisions of other laws and regulations so that the interpretation of laws and regulations may not be out of place or deviate from the legal system of a country. ${ }^{22}$ Third, historical interpretation is a method of interpretation of the meaning of laws according to its occurrence by examining history, both its legal history and the history of the law. In other words, the historical interpretation includes interpretation of the history of the law (wet historisch), and legal history (recht historischt). Interpretation, according to the history of wet historisch is to look for the purpose of the legislation as seen by the legislators when the law was formed. Historical legal interpretation (recht historischt) is a method of interpretation that understands the law in the context of its legal history.

Sudikno Mertokusumo, Bab-bab Tentang Penemuan Hukum, Bandung: PT. Citra Aditya Bakti, 1993, p. 4 Johny Ibrahim, Teori \& Metodologi Penelitian Hukum Normatif, Malang: Bayumedia, 2011, p. 221.

Ahmad Rifai, Penemuan Hukum oleh Hakim dalam Perspektif Hukum Progresif, Jakarta: Sinar Grafika, 2010, p. 67. 
In the case of using a grammatical interpretation to explore the meaning contained in Article 35(c) of the Prosecutor's Law, the matter that needs to be questioned first is whether the meaning of the provision that the Attorney General can dismiss a case is interpreted as a decision based on the results of the Attorney General's assessment itself or as the implementation of the duty of service to the state to serve the public interest (the interests of the nation and the state and/or the interests of the wider community). If a dismissal of a case is carried out only based on a subjective judgment of the Attorney General, it would be more appropriate to formulate 'untuk kepentingan umum' (literally means on behalf of the public interest) not 'demi kepentingan umum' (for the public interest). In the Kamus Besar Bahasa Indonesia (Indonesian Dictionary), the word untuk means purpose or aim. Then, if it is formulated "on behalf of the public interest", the dismissal of a case is intended based on the interest of the public. It will be an inherent that the Attorney General has the authority to interpret the term 'public interest', or whether a situation has been in a certain situation so that it can be categorized as "public interest". ${ }^{23}$

However, this is not the case with Article 35(c) of the Prosecutor's Law which uses the word "for" in front of the term "public interest" and limits the meaning of "public interest" in the elucidation of the provision as "the interests of the nation and the state and/or the interests of the wider community". It also determines and limits that the decision-making to dismiss a case is carried out after considering the suggestions and opinions of state power bodies that is correlated with the problem. In this case, the Attorney General has the duty to serve the public interest and is not a representation of the public interest itself. Thus, dismissal of a case for the public interest can be interpreted as cancelling a case that is carried out in the interests of the wider community that is voiced or represented by state institutions based on their assessment. ${ }^{24}$

Furthermore, in interpreting the elucidation of Article 35(c) of the Prosecutor's Law, which requires the Attorney General to pay attention to the advices of correlated state power bodies, it must be understood that this condition is not a restriction to prevent misuse of authority possessed by the Attorney General in ruling out a case. This is because the suggestions and opinions of other state power bodies have absolutely no binding power to the Attorney General. If we understand the grammatical meaning, the Attorney General is only asked to pay attention. The Attorney General does not need to follow the advice given and, consequently, has no obligation at all to follow the advices and the opinions of the state authority bodies. Therefore, the consideration to do or not to do case dismissal is at the hand of the Attorney General's office. Thus, it can be interpreted that the authority of

23 Dhea Yudhista (ed.), “Keterangan ahli Tentang Konstitusionalitas Pasal 35 Huruf C Undang-Undang Republik Indonesia Nomor 16 Tahun 2004 Tentang Kejaksaan Republik Indonesia terhadap Undang-Undang Dasar Negara Republik Indonesia Tahun 1945", https://fh.umj.ac.id/keterangan-ahli-tentang-konstitusionalitasarticle-35-huruf-c-undang-undang-republik-indonesia-nomor-16-tahun-2004-tentang-kejaksaan-republik-indonesia-terhadap-undang-undang-dasar-negera-republik-indon/, accessed on April 2018. 
the Attorney General to dismiss a case for the public interest is a very broad free authority that is not in line with the meaning "in the public interest" but closer to the meaning "for the public interest"

Based on a systematic legal interpretation, juridically, some laws and regulations mention the term 'public interest' with the following meanings.

a. Elucidation of Article 5 letter d of Law Number 30 of 2002 on the Corruption Eradication Commission explains that 'the public interest' is the principle that prioritizes public welfare in objective, accommodative, and selective manner.

b. Implicit in Article 49 of Law Number 5 of 1986 on the State Administrative Court, it states that 'the public interest' is connected to an urgent situation for the public needs, such as a state of natural disaster or an extraordinary condition.

c. Article 18 of Law Number 5 of 1960 on the Basic Agrarian Law affirms that 'public interest' is a trait that is linked to activities for the benefit of the people, the common interests of the nation, and the state and the interests of development.

d. According to Article 1 Number 7 of Law Number 2 of 2002 on the Indonesian National Police, the 'public interest' is in the interests of community/or the interests of the nation and the state in order to guarantee state security.

e. According to Article 1, point e of the decree of the President of Indonesia Number 55 of 1993, the 'public interest' is in the interests of all levels of society.

This study has not found any legal instrument that explains or gives criteria, parameters, or benchmarks related to the term 'the public interest' or the interests of the nation and state and/or the interests of the wider community. This study only found various definitions of 'public interest'.

Furthermore, by attempting to interpret historical law, it must be traced to the intent of the lawmakers stated in the memorie van toelichting of the discussion of law draft on the Indonesian prosecutor's office. In the minutes of the discussion session of the Attorney General's Law of the Republic of Indonesia, since the provisions containing the authority of the Attorney General to dismiss a case for the public interest from, there are no criteria or explanations of unbiased or abstract meanings about 'public interests' and interests of nation and state and/or public interest. The only discussion related to the criteria in this regard is the scope of public interest, in the minutes of the discussion session of Law Number 15 of 1961 on the Basic Provisions of the Prosecutor's Office of the Republic of Indonesia.

In the minutes of the hearing, Dahlan Kahar, a member of the House of Representatives (DPR) who presented at the time of the discussion of the Draft of the Law Number 15 of 1961 on the Principal Provisions of the Prosecutor's Office of the Republic of Indonesia, raised a question. The question is whether the authority to dismiss a case for the public interest is only held by the Attorney General? What about minor cases, such as theft of car cots? Does the prosecutor in the court does not have the authority to dismiss such case? Should the prosecutor request permission from the attorney general? The question was responded by the 
statement of the Attorney General Mr. Gunawan that “... they don't consider about thefts, for example thefts of sweet potatoes, sugar cane, and so on...". ${ }^{25}$ Therefore, the dismissal of a case for the public interest is not intended for small cases, for example potato theft, which can still be resolved by the public prosecutor.

Furthermore, to determine the criteria, parameters, or limits of the term 'public interest' is not an easy matter. Even the experts also have different views about the meaning of 'public interest'. The Indonesian dictionary, what is meant by umum (literally means general) is defined as all or a whole, not involving only specific or precise matters, for many people, or for anyone. Then, kepentingan (lit. interests) is defined as needs, requirements, very necessary things, or very important things. Therefore, 'the public interest' can be interpreted as a very important need or need for all people. That definition can also be compared to the needs and requirements that are very necessary and primary for the people and for anyone. ${ }^{26}$ Franz Magnis Suseno says that 'the public interest' is a task that must be endeavored by the state to support the achievement of public welfare. ${ }^{27}$ Alex Lanur argues that 'public interests' can be explained as goodness which is actually the least good for most citizens, justice, and welfare. Peace can also be included in the public interest category. ${ }^{28}$ The last, The Liang Gie says that the public interest is all things that encourage the attainment of peace, economic stability, and progress in the life of society in addition to the affairs that concern the state and the people as a whole. ${ }^{29}$

According to van Bemmelen, ${ }^{30}$ there are three reasons for not prosecuting, which at least can be used as a reference in the future to determine criteria, parameters, or limits the term "public interest". They are as follows.

1. For the sake of the State (staats belang)

2. State interests do not require a prosecution if there is a possibility that certain aspects of a case will get unbalanced pressure. Therefore, a suspicion that arises among the people, in these circumstances, may cause a large loss to the state. For example, a prosecution may result in an unwanted reveal (openbaring) of state secrets.

3. For the benefit of the community (maatschapelijk belang)

4. A criminal act is not sued because, socially, it cannot be accounted for. This category includes thoughts that have been or are changing in society. For example, opinions that can change or are changing about punishment for moral offenses.

25 Minutes of Session DPR GR Session III, 11 1 th Joint Meeting of the entire commission, May 29, 1961, p. 30.

26 See also the word" penting" and "umum" in W.J.S Poerwadarminta, Kamus Umum Bahasa Indonesia, Balai Pustaka, Jakarta: 1993, p.732 and p. 1126.

27 Franza Magnis Suseno, Etika Politik Prinsip-Prinsip Moral Dasar Kenegaraan Modern, Jakarta: Gramedia, 1987, p. 314.

28 Alex Lanur in Majalah Hidup, Jakarta, 19 Juni 1994, pp. 40-41.

29 The Liang Gie, Pertumbuhan Pemerintah Daerah di Negara Republik Indonesia, Volume III, Jakarta: Gunung Agung, 1968, p. 159.

30 See Arin Karniasari, "Tinjauan Teoritis, Historis, Yuridis dan Praktis terhadap Wewenang Jaksa Agung dalam Mengesampingkan Perkara Demi Kepentingan Umum", thesis, Faculty of Law Universitas Indonesia, 2012, p. 115. 


\section{For Personal Interest (particular belang)}

6. These category covers the personal interests not to prosecute. This is only minor cases. Then, if a person commits a crime has paid the loss and, in this situation, the community does not have enough interest in prosecution or punishment. For the perpetrator, personal interest is too heavily affected compared to the possibility of the outcome of a criminal process, which in the public interest will not be beneficial. Therefore, the benefits obtained from the prosecution are not balanced with the losses incurred against the defendant and the community.

\section{The Effects of the Application of the Principle of Opportunity to the Principle of Equality Before the Law}

The rule of law is a means that functions to control the values of justice and human rights, which can be normalized and protected within the legal system. A legal state does not separate between human rights and state power and how to use and to restrict the power of the state. They are closely attached and support each other. Humans as social beings, in each of their associations, will surely encounter various rights and obligations, as well as other human interests. The problem is how then the diversity of rights, obligations, and interests can run without injuring other human rights, both individually and in-groups. Human rights are growing and developing at a time when human rights begin to be considered and to fight against attacks or dangers arising from the power of a society or the State. In essence, the issue of human rights revolves around the relationship between humans as individuals and society because, when a country becomes stronger and more widespread, it will forcibly intervene the environment of personal rights which may result in diminishing personal rights. ${ }^{31}$

Scheltema, as quoted by Bernard Arief Sidharta, says that the concept of modern welfare rechtsstaat, or modern law state or welfare state, has five legal aspects as follows. ${ }^{32}$

1. Recognition, respect, and protection of human rights rooted in respect for human dignity, which is the fundamental principle of the rule of law.

2. Legal certainty that implies several things, i.e. citizens must be free from unpredictable actions of the government and its apparatus and arbitrary actions; the government and its apparatus must be bound and subject to the rules of positive law; and all actions of the government and its apparatus must be based on positive law rules as the legal basis.

3. Equality, namely that the government and its apparatus must give equal treatment to all people and the law also applies equally to everyone.

Ahmad Kosasih, HAM dalam Perspektif Islam, Jakarta: Salembah Diniyah, 2003, p. 20.

32 Bernard Arief Sidharta, Refleksi Tentang Struktur Ilmu Hukum: Sebuah Penelitian Tentang Fundasi Kefilsafatan dan Sifat Keilmuan IImu Hukum Sebagai Landasan Pengembangan IImu Hukum Nasional Indonesia, $2^{\text {nd }}$ edition, Bandung: Mandar Maju, 2000, p. 49. See also Jimly Asshidiqie, "Negara Hukum Indonesia", presented on 'General Lecture in the Inauguration of the Central Executive Board of the Alumni Association of Universitas Jayabaya', Jakarta, January 23, 2010. 
4. Democracy, this principle is related to the method of decision making; every citizen has the same possibilities and opportunities to influence government decisions or actions.

5. The government and its officials carry out the function of serving the people, which is outlined in the general principles of good governance.

Paul Scholten also believes that, a new country can be considered as a legal state if there is a limitation of state power to its citizens by the rule of law..$^{33} \mathrm{~A}$ state of law requires that all actions or activities of authorities must have a clear legal basis or legality. The legitimacy of the state to govern, because the state is neutral, does not take sides, stands above all classes of society, and serves the public interest. ${ }^{34}$

HR Lunshof who says that the principle of legality must remain a major element in the understanding of the welfare state expresses an almost similar opinion. In connection with that, it is stated that the elements of the rule of law of the twentieth century are ${ }^{35}$

1. Separation between the legislator, the implementer of the law, and the judiciary;

2. Formulation of legislators in a democratic manner;

3. The principle of legality; and

4. Recognition of human rights.

Hans Kelsen also formulated the concept of the rule of law in relation to democracy and human rights by arguing four rechtstaat conditions. ${ }^{36}$ They are as follows. ${ }^{37}$

1. The state lives are in line with the constitution and laws. The process of which is made by the parliament. The people elect parliamentarians.

2. The state regulates the mechanism of accountability for every policy and action taken by the state elite.

3. The state guarantees the independence of judicial power.

4. The state protects human rights.

Drawing general conclusion from previous explanations related to the characteristics or concepts of the rule of law and human rights, a legal state protects the human rights in such a way. Then, a state that does not protect human rights cannot be categorized as a state of law. Even, it can be categorized as a dictatorial state with the administration of an authoritarian government. Justice and human rights are elements and conditions that must be fulfilled by a legal state as buffers and main pillars because a country that does not make justice and human rights pillars of the life of the nation and the state cannot be considered as a legal state.

\footnotetext{
Ramdlon Naning, Cita dan Citra Hak Asasi Manusia di Indonesia, Jakarta: Lembaga Kriminologi Universitas Indonesia-Program Penunjang Bantuan Hukum Indonesia, 1983, p. 26.

34 Arief Budiman, Teori Negara: Negara Kekuasaan dan Ideologi, Jakarta: Gramedia Pustaka Utama, 1996, p. 1.

35 Ibid.

36 HR Lunshof in Azhari, Negara Hukum Indonesia, Analisis Yuridis Normatif Tentang Unsur-Unsurnya, Jakarta: UI Press, 1995, p. 30.

37 Hans Kelsen in Ni'matul Huda and Imam Nasef, Penataan Demokrasi dan Pemilu di Indonesia Pasca Reformasi, Jakarta: Kencana, 2017, p. 199.
} 
One form of protection and guarantee of human rights in the criminal justice process in Indonesia is that there must be equal treatment for each person before the law by not making a difference in treatment. ${ }^{38}$

In Indonesia, the equality before the law is a part of human rights protected by the constitution. The recognition of equality before the law lies in the Indonesian state constitution, namely in Article 27(1) of the 1945 Constitution. It states "Segala warga negara bersamaan kedudukannya di dalam hukum dan pemerintahan wajib menjunjung tinggi hukum dan pemerintahan itu dengan tidak ada kecualinya" (All citizens are equal in the law and the government must uphold the law and the governance with no exception). Likewise, the Article 28D of the 1945 Constitution states "Setiap orang berhak atas pengakuan, jaminan, perlindungan, dan kepastian hukum yang adil serta perlakukan yang sama di hadapan hukum" (Everyone has the right to the recognition, guarantee, protection, and fair legal certainty and equal treatment before the law). Then, Article 281 paragraph (1) includes a right that everyone has the right to be recognized as a person before the law. The Article 281 paragraph (2) further states that everyone is free from discriminatory treatment on any basis and has the right to the protection against discriminatory treatment. Thus, the concept of equality before the law has been existed in the constitution, which is the highest recognition in the system of legislation in the state. ${ }^{39}$

The recognition of the principle of equality before the law in the constitution and legislation in Indonesia brings law consequences, including formal criminal law or criminal procedural law. In the context of the Indonesian criminal justice system, anyone who is suspected of having committed a crime, without exception and discrimination, must be carried out through a fair and correct criminal justice process, which is carried out in a coherent and sustainable manner in line with the procedural law. In relation to the relationship between the principle of equality before the law and the principle of opportunity, Mien Rukmini says that the regulation of human rights in Indonesia is a problem that is closely related to the criminal justice system. Therefore, to realize Indonesia's criminal justice system that is just and right, it is very relevant to conduct research on the relationship of the application of the principle of opportunity and the principle of equality before the law, which is the main pillar in the framework of the rule of law. ${ }^{40}$

Some parties have debated the recognition of the principle of opportunity in the Indonesian criminal justice system. The principle of opportunity enables a criminal case that has fulfilled formal and material requirements (P-21) and should proceed to the trial stage can be terminated through the authority of the Attorney General on the grounds that it is 'for the public interest'. Someone who is strongly

Read general explanation number 3(a) on Criminal Procedure Code.

39 Eka N.A.M Sihombing, "Mendorong Pembentukan Peraturan Daerah Tentang Bantuan Hukum Di Provinsi Sumatera Utara" Op.cit., p. 83.

40 Mien Rukmini, Perlindungan HAM Melalui Asas Praduga Tidak Bersalah dan Asas Persamaan Kedudukan dl Hadapan Hukum pada Peradilan Pidana Indonesia, Bandung: PT Alumni, 2003, p. 69. 
suspected of violating the criminal law may be treated preferentially to be free from the law through the authority of the Attorney General. The authority of the Attorney General can be said as an extraordinary law enforcement process because a criminal case actually has to go through the stages set out in the criminal procedural law, namely through the stages of preliminary investigation, full investigation, pre-prosecution, prosecution, trial examination, court decision, and execution of the judge's decision. The series of criminal procedural law enforcement processes must be followed in a coherent and sustainable manner. Then, law enforcement officers, in carrying out their duties and authorities, must be subject to the provisions that have been regulated in criminal procedural law because the function of the criminal procedural law is to limit state power in acting against every citizen involved in the criminal justice process. ${ }^{41}$

Currently in Indonesia, law enforcement still seems selective and it is usual to depend on the social status of a person. The process of law enforcement will stagnate when facing a big case where the suspect/defendant has power, is in the protection of the owner of the power, or wallowing in property. However, it will be another story when it deals with small cases: the law enforcement process will be very fast and swift.

There was a case that happened to an old lady named Minah, a 55-year-old woman, a resident of Sidoharjo Hamlet, Banyumas Regency who was accused of stealing 3 kilograms of cocoa, which in fact only took 3 cocoa that had fallen from the tree. ${ }^{42}$ Because of her action in the garden owned by PT Rumpun Sari Antam, in August 2008, the Panel of Judges sentenced him to 1 month 15 days in prison, as well as a 30-day trial period. ${ }^{43}$ The verdict arose amid the chaotic corruption of the mega billion corruption case in Jakarta, the Bank Century case. Spontaneous question marks appear in the public's mind: why are law enforcement officials so fast and responsive in handling small theft cases as what Minah did, while big cases of theft of state money or corruption involving state officials are so difficult to uncover.

Another example of the principle of opportunity is the dismissal of the case that befell Abraham Samad, former head of the Corruption Eradication Commission (KPK) in March 2016 with the issuance of a decree (Tap. 012/A/JA/03/2016). The case involving Abraham Samad is considered by some to be a form of criminalization of the KPK and efforts to weaken corruption eradication in Indonesia. Then as KPK leader Abraham Samad was considered as an icon of anti-corruption fighters who had contributed a lot in eradicating corruption in Indonesia during his tenure. According to the Attorney General, the Abraham Samad case must be dismissed

41 Mardjono Reksodiputro, Hak Asasi Manusia Dalam Sistem Peradilan Pidana, Jakarta: Pusat Pelayanan Keadilan dan Pengabdian Hukum, 1994, p. 25.

42 Saladin Ayyubi, "Dituduh curi Buah Kakao 3 Biji Nenek Ditahan Rumah 3 Bulan”, https://news.okezone.com/ read/2009/11/20/340/277724/dituduh-curi-buah-kakao-3-biji-nenek-ditahan-rumah-3-bulan, accessed on April 2018.

43 Republika, "Hakim tersedu-sedu Bacakan Putusan Nenek minah", http://www.republika.co.id/berita/breakingnews/hukum/09/11/20/90390-hakim-tersedu-sedu-bacakan-putusan-nenek-minah, accessed on April 2018. 
because it will cause controversy in the wider community if the case continues. ${ }^{44}$

However, the position of Abraham Samad as a KPK leader should not be used as a reason for the dismissal, considering that the spirit of eradicating corruption would not diminish even though the case was not dismissed. There may even be a paradigm in the community towards the case that Abraham Samad is a person who is 'invulnerable' and the KPK is a place for people who are 'immune' to legal bondage because they are considered to be people who are 'strong', have a shield, cannot be subject to legal sanctions, or 'holy' people who never make mistakes. Even the dismissal of Abraham Samad case can raise the question: is the dismissal is really for 'the public interest' or Abraham Samad's own interests, such as what are the 'public interest' parameters, criteria or benchmarks used by the Attorney General.

The dismissal of Abraham Samad case has caused various implications, especially for the Indonesian people who aspire to justice in law enforcement because anyone in Indonesia is equal before the law without exception. The provision of a dismissal decree based on Article 35(c) the Prosecutor's Law shows that there are some people who have a special position before the law and are 'immune' to the legal process.

If we use the point of view of the principle of equality before the law recognized in the Indonesian constitution, then anyone without exception and without discrimination, whether he is an official who has high power, rich people, poor people, all have the same position before the law. In the criminal justice system, a person who is suspected of committing a crime, and the case file has fulfilled formal and material requirements, must be taken to the court by the Public Prosecutor before the panel of judges.

Recognition and guarantee of equality before the law has been very clearly recognized and included in the Indonesian constitution. The Indonesian criminal justice system also regulates linearly the equality before the law with the state constitution, in the Criminal Procedural Law to affirm that Indonesia guarantees equality before the law for every person undergoing a criminal procedural law process. This can be known in the general explanation of the Criminal Procedure Code Number 3 Letter (a). It confirms that the treatment is the same for each person before the law by not making different treatments. In essence, the principle of equality before the law arises with the aim to provide and to create guarantees in obtaining justice for all people regardless of their background. When a person is suspected of committing a crime, a right and fair legal process must settle the case.

The authority held by the Attorney General to dismiss a case for public interest (deponering/seponering) is stated in the Provisions of Article 35(c) of the Prosecutor's Law and its explanation. It does not have legal certainty because it is multi-interpretative without clear criteria and parameters, firm, and limitation. It

\footnotetext{
44 Voa Indonesia, "Kasus Abraham Samad dan Bambang Widjojanto", http://www.voaindonesia.com/a/jagung-deponering-kasus-abraham-samad-dan-bambangwidjojanto--/3219269.html, accessed on April 2018.
} 
has denied the right to equal treatment before the law as affirmed by Article 28D paragraph (1) of the 1945 Constitution. Special treatment before the law for some people will result in a violation on victims of the criminal case ruled out. The victim may become a person whose rights are not recognized before the law. The term is recognized as stipulated in Article 28I Paragraph (1) of the 1945 Constitution that everyone has the right to be recognized as a person before the law. In addition, the authority of case dismissal in the provisions of Article 35(c) of the Prosecutor's Law is a discriminatory form that violates the provisions of Article 28I Paragraph (2) of the 1945 Constitution that a person suspected of having committed a crime can be treated differently by not continuing legal process.

The suspect whose case is set aside for the public interest must also bear the logical consequences because the dismissal of a case for the public interest without rational or accountable reasons reveals some consequences as follows.

1. The suspect is considered guilty because a dismissal is carried out for case that has met formal and material requirements (P-21).

2. The suspect cannot defend in court to prove that she/he is innocent.

3. The suspect is given privileges before the law because they can be free from court proceedings, which means a form of denial of the principle of equality before the law.

4. Crimes that are alleged to the suspect are considered to have existed and have occurred.

The principle of equality before the law must be a supporting pillar that is solid from a state law building, making the law the supreme commander in the life of the nation and state. Based on the point of view of criminal procedural law, the principle of equality before the law seems to be transformed into the principle of legality. It is because the principle of legality requires the same thing with the principle of equality before the law that is, in order for the criminal justice process to be carried out in a coherent and sustainable manner. All persons suspected of committing crimes must be processed in accordance with the right and fair law without discriminating and without giving special treatment to certain people, either punished or not punished by judge's decision in court.

The authority to dismiss a case for the public interest based on the provisions of Article 35(c) of the Prosecutor's Law has the potential to injure the upholding of the principle of legal certainty. It is because the term 'public interest' in these provisions does not have clear, firm, and limitative criteria and parameters. It can be interpreted subjectively, which also has the potential for abuse of authority and power. It shows inconsistency, has a negative influence, and has been incoherent with the principle of equality before the law, which is a pillar supporting the rule of law. The application of the principle of opportunity based on the provisions of Article 35(c) of the Prosecutor's Law can lead to the fall of authority from the principle of equality before the law because it is neglected, or excluded, by the implementation 
of the principle of opportunity. Prof. Romli says that if there are still laws that give privileges to the treatment of an individual, then the law is diametrically opposed to the 1945 Constitution of the Republic of Indonesia. The constitution states explicitly that the right of everyone to be treated equally before the law in any position. ${ }^{45}$

\section{E. Relevance of the Application of the Principle of Opportunity in the Indonesian Criminal Justice System}

The dismissal of a case for the public interest is a manifestation of the principle of opportunity. The habit has existed since the Dutch colonial era. Based a historical and legal point of view, the existence of the principle of opportunity in the criminal justice system in Indonesia has been recognized long before Indonesia's independence and sovereignty as an unwritten law.

"Di Sulawesi Selatan rumpun keluarga besar yang disebut appang dan rapu yang dikepalai oleh anang bergabung berserikat dengan keluargakeluarga lain. Federasi keluarga-keluarga itu kemudian dikepalai oleh seorang ulu anang yang dipilih oleh dan di antara para anang. Para anang dan ulu anang inilah yang memimpin masyarakat dengan fungsi-fungsi eksekutif, legislatif, dan yudikatif. Pada tingkat federasi dibentuk badan-peradilan yang diketuai oleh ulu anang dan para anang. Oleh karena hukum pidana masih bersifat keperdataan maka terserahlah pada orang atau kelompoknya menentukan menuntut pelanggar adat atau tidak. Maka dengan sendirinya wewenang untuk mendeponir perkara berada ditangan kelompoknya. Kalau ia atau kelompoknya memandang lebih bijaksana tidak menuntut pelanggar demi kepentingan kelompok besar (extended family)atau serikat keluarga, maka lahirlah asas oportunitas sebagaimana kita kenal sekarang." 46

(In South Sulawesi, large family groups called appang and rapu are headed by anang joined together with other families. The federation of families was then headed by an ulu who is chosen by and among the children. These anang and ulu anang lead the community with executive, legislative, and judicial functions. At the federation level, the judiciary was formed, chaired by ulu anang and anang. Because criminal law is still civil, it is up to the person or group to determine whether or not a violator is sued. Therefore, the authority to call the case is in the hands of the group. If the group considers it is wiser not to sue violators for the benefit of large groups (extended family) or family unions, then the principle of opportunity is used, similar to

Abdul Selamat Nazar, "Penerapan Asas Equality Before The Law Dalam Tindak Pidana Korupsi (Studi Tentang Bentuk Penahanan Pada Sidang Pengadilan Tipikor)", Jurnal Nestor Magister Hukum Universitas Tanjungpura, Vol. 2, No. 2, 2012, p. 21.

46 A.Z. Abidin, Bunga Rampai Hukum Pidana, Sejarah dan Perkembangan Asas Oportunitas di Indonesia, Jakarta: PT. Pradnya Paramita, 1983, pp. 90-91. 
what we know today.)

The principle is still applied after Indonesia reached independence and has not been regulated in the law. One example is the dismissal of the Asa Bafagih case for the public interest by the Attorney General Soeprapto in 1953, which is about before the Law on the Principles of the Prosecutor's Office of the Republic of Indonesia regulated the authority of the Attorney General in dismissal of case for the public interest. ${ }^{47}$ The starting point of the principle of opportunity is confirmed in written code, with the enactment of the Government Regulation in Lieu of Law Number 24 of 1960 on Investigation, Prosecution, and Examination of Corruption Crimes. Article 4 mentions that prosecutors are only allowed to dismiss corruption cases based on the attorney general's order. Furthermore, recognition of the principle of opportunity is emphasized in Article 8 of Law Number 15 of 1961 on the Basic Provisions of the Prosecutor's Office of the Republic of Indonesia. The article regulates that The Attorney General can set aside a case based on public interest. Then it was later amended in Law Number 5 of 1991 on the Prosecutor's Office of the Republic of Indonesia. Article 32 (c) states that The Attorney General has duties and authority, one of them is to dismiss a case for the public interest. Furthermore, the Attorney General's authority to dismiss a case for the public interest is regulated in Article 35(c) of the Prosecutor's Law, which states that "the Attorney General has the duties and the authorities", one of them is "to dismiss a case for the sake of public".

Historically and juridically, the existence of the principle of opportunity has been recognized for a long time in the Indonesian criminal justice system. However, at the level of implementation it is acknowledged to cause many problems, especially since the principle of equality before the law is explicitly introduced in the Indonesian constitution. The implementation of the principle of opportunity based on the provisions of Article 35(c) of the Prosecutor's Law can result in the violation of the constitutional rights of some people. The emergence of problems related to the application of the principle of opportunity based on the provisions of Article 35(c) of the Prosecutor's Law in the criminal justice system in Indonesia is considered normal. First, this is due to the regulation of the principle of opportunity in the legislation that is positioned very floating, does not reflect the principle lex certa, as well as incomplete and comprehensive arrangements regarding the implementation of the principle of opportunity. Second, there is unpreparedness of the state to implement the principle of opportunity.

The authority is possessed by the Attorney General to dismiss case for the public interest as stipulated in Article 35(c) of the Prosecutor's Law. Actually, it is an autonomous right to form the Law. However, the problem is whether the formulation of the provisions established by the Lawmakers in facilitating this authority has guaranteed legal certainty, fair and impartial legal processes, and placed everyone before the law in the same position and degree. The establishment of strong laws

$47 \quad$ lip D. Yahya, Mengadili Menteri Memeriksa Perwira Jaksa Agung Soeprapto dan Penegakan Hukum di Indonesia Periode 1950-1959, Jakarta: PT. Gramedia Pustaka Utama, 2004, p. 179. 
(legislation) lies in legal language that focuses on the lex certa principle, which requires the realization of legal certainty and does not contain the multi-interpretive nature of a rule of law. The absence of adequate or even multiple interpretations of a rule of law can lead to a potential constitutional loss of a person.

The regulation of the principle of opportunity in the Provisions of Article 35(c) of the Prosecutor's Law can be concluded as not fulfilling the principle of lex certa because of the understanding of "public interest". The provision covers "the interests of the nation and the state and/or the interests of the wider community" as stated in the explanation of Article 35(c) of the Law of The Prosecutor's Office can be interpreted very broadly and cannot know the limitations and parameters. Without clear boundaries and parameters that can lead to negative excesses in the use of authority by the Attorney General, the interpretation of the meaning of "public interest" is left entirely to the Attorney General as the party that has the authority to determine public interest, which is a formal condition in dismissal of case. Understanding the meaning of "public interest" should be aimed to protect greater interests. It has greater benefits for the community or the state, not for the benefit of individuals. It is very difficult to measure and assess because parties can measure and determine the existence or not of interests the general who is harmed or the existence or greater benefit for the benefit of the nation and the state is based on the subjective attorney's own subjective assessment. This is because the suggestions and opinions of other state power bodies have absolutely no binding power to the Attorney General. The Attorney General is only required to pay attention without the need to follow the advice given, so that consideration is made to do or not to dismiss case back to the Attorney General's hand. Thus, the dismissal of a case of some people carried out by the Attorney General cannot always be identified as the interests of the community, nation, or state, because if that happens then it can reduce the meaning of public interest into individual interests.

The absence of clear criteria, measurements, limits, and parameters regarding the understanding of 'the interests of the nation and the state and/or the interests of the wider community' and the fact that suggestions and opinions of other state power bodies have made the authority to dismiss case as an authority that cannot be controlled and restricted. Therefore, it is very vulnerable to abuse of authority. Thus, the application of the principle of opportunity in the criminal justice system in Indonesia requires strict or rigid restrictions or conditions because the principle of opportunity is a very real manifestation of the denial or exclusion of equality before the law, which is very strict, recognized, protected, and guaranteed by the state.

Comprehensively, Indonesia does not yet have the readiness to implement the principle of opportunity, both in terms of technical and juridical. From the juridical aspect, the absence of a good and adequate legal rule regarding the principle of opportunity can make it used as a tool to carry out legal smuggling for interests other than the legal interest, to protect certain people who are involved in legal cases. The 
provisions of Article 35(c) The Prosecutor's Law and its elucidation, which are the rules of implementing the principle of opportunity are multi-interpretive rules and do not fulfill the lex certa principle. Then, for reasons that are not necessarily rational and unfounded, it can impose value and authority of the principle of equality before the law because it contradicts everyone's right to obtain equal legal recognition, guarantee, protection, and legal certainty, and treatment before the law.

Then the absence of other legal instruments than the provisions of Article 35(c) of the Prosecutor's Law, whether in the form of Laws, Government Regulations, or guidelines in the form of decrees, which regulate procedures and mechanisms for the implementation of the principle of opportunity, indicates the unpreparedness of the state. It also causes unpreparedness of an Attorney General to implement the principle of opportunity. In the practice of implementing the principle of opportunity in the Indonesian criminal justice system, the procedures and mechanisms for implementing the principle of opportunity are not based on legislation but are only situational and conditional. The legal instruments governing the procedures and mechanisms for implementing the principle of opportunity are very fundamental. It is because, in addition to the process and procedures for implementing the principle of opportunity, it also guarantees the realization of legal certainty and guarantees equality before the law. Legal certainty is one of the main pillars in a rule of law because every person must be free from the actions of the government and its arbitrary apparatus, state administrators, including judicial elements. They all must submit and bind themselves to the applicable legal rules, and every action must be based on applicable legal rules. Likewise, equality before the law is one of the main pillars that support the building of the state of law, which guarantees the human rights of citizens to be treated equally before the law with a fair and due process of law when dealing with law.

Based on the technical aspect, the Attorney General's unpreparedness to implement the principle of opportunity in the criminal justice system can be seen from the absence of the Prosecutor's Office that is given special duties to assist the Attorney General in examining and reviewing criminal cases to be dismissed for the public interest. It will be very vulnerable once there is abuse of authority in implementing the principle of opportunity.

This study is in the argument that the implementation of the principle of opportunity based on the provisions of Article 35(c) of the Prosecutor's Law is irrelevant to be applied in the Indonesian criminal justice system. Its legislative policies are less comprehensive so that it can be used as a loophole for legal smuggling for other intentions.

However, even though it is considered to have values that are contrary to the principle of equality before the law, it cannot be denied that the principle of opportunity also has the values of goodness to compensate for the sharpness of the very rigid principle of legality. Considering restorative justice that engulfs various 
countries in the world, the application of the principle of opportunity cannot be ignored, of course with due regard to the legal objectives to be achieved, namely certainty, usefulness, and justice. The policy that gives authority to cut a chain from the judicial process is to realize the legal benefits for the benefit of the community and is a means to protect, to guide, and to contribute to the society. If at present the rules for the implementation of the principle of opportunity as a legal institution are no longer able to maintain and manifest the essential forms of law, namely justice, truth and orderliness, then the law itself needs to be reviewed consciously. ${ }^{48}$

Therefore, in order for the principle of opportunity to be relevant to be applied in the Indonesian criminal justice system, two choices can be used as a solution to form legislation policy on the application of the principle of opportunity in the Indonesian criminal justice system.

First, Indonesia can adopt a modification of the policy of applying the principle of opportunity in various countries in the world to reformulate the policy of applying the principle of opportunity in the Indonesian criminal justice system. For example, some of them are Japan, the Netherlands, and Norway. In Japan and the Netherlands, the benchmark for applying the principle of opportunity is if the case concerns trivial cases, old ages, and damage has been settled. The application of this principle is then developed with the possibility of imposing certain conditions, among others, by paying a fine (transactie)..$^{49}$

In Japan, prosecutors generally can suspend prosecutions by considering several aspects. The aspects, among others, are ages, character, and circumstances (too young or too old); never convicted; the weight or dimensions of actions; crimes committed due to being provoked by the victim, the loss of the victim not too heavy; paying compensation to the victim, the feeling of the victim already restored; the peace between the victim and the perpetrator; the crime committed not affecting the community; the perpetrator feeling sorry for her/his actions. ${ }^{50}$ According to Koici Miyazawa, Japanese prosecutors did not prosecute more than $50 \%$ of cases of theft and offenses because the perpetrators were old. Then in Japan, the prosecutor will not sue if she/he is in doubt whether the perpetrator will be sentenced or free. Thus, prosecutors in Japan will only hand over cases to the court if they are sure the perpetrator will be sentenced. ${ }^{51}$

Then, Norway has adopted the principle of opportunity since 1887 by giving a wide discretion to the Prosecutors. Prosecutors in Norway may impose sentences outside the court, according to Supreme Court Justice Helge Röstad (UNAFEI Report, 1986). Therefore, the attorney's discretionary authority in Norway is wider than the discretion of prosecutors in the Netherlands and Japan.

Djoko Prakoso, Eksistensi Jaksa Ditengah-tengah Masyarakat, Jakarta: Ghalia Indonesia, 1985, p. 97.

49 See Andi Hamzah, (et.al.), Laporan Analisis dan Evaluasi Hukum Tentang Pelaksanaan Asas Oportunitas dalam Hukum Acara Pidana, Jakarta: BPHN, 2006, pp. 15-16.

50 Andi Hamzah in the Minutes of the Case Number 29/Puu-Xiv/2016, p. 16

51 lbid. 
Norwegian Prosecutors can even impose penalties or impose sanctions without court intervention. The imposition of sanctions or actions is known as unnlatese patale. For more severe cases, they must seek approval from the Attorney General; so, the Prosecutor in Norway is called a semi judge..$^{52}$

Prosecutors in the United States and Britain do not recognize the term principle of opportunity. Nonetheless, both countries practice the principle of opportunity with the term discretionary prosecution. Prosecutors in the United States (District Attorney and State Attorney) are even more dominant in exercising their powers of discretion at the stage of the criminal process from the beginning of the investigation to the post trial. The decision to demand or not is almost completely free from the influence of other people or bodies. They know what is called a "plea bargaining" as the prosecutors can stop prosecution or compromise. The prosecutor can reduce the claim with the recognition of the defendant, the defendant can plead guilty before the trial begins, if the prosecutor agrees, then the prosecutor can reduce the charge or give a recommendation to the court to impose a lighter sentence. ${ }^{53}$

Thus, in some countries that adhere to the principle of opportunity, the notion of dismissal of case develops more broadly, not only based on reasons of public interest only but for more varied considerations.

Second choice, legislators must be able to formulate criteria of public interest or the interests of the nation and state and/or the interests of the wider community based on philosophical, sociological, legal, economic aspects, by upholding justice and legal certainty, or by making procedures and mechanisms that presumably can measure or determine criteria of public interest.

For example, to measure whether or not there is a "public interest", the implementation of the principle of opportunity which is to dismiss case for the public interest can be carried out by the Attorney General after obtaining approval from the House of Representatives (DPR). Then, the suggestions and opinions of the DPR have a binding nature. This is quite reasonable because the DPR is a representative institution of all Indonesian people who are elected as representatives of the people to voice the aspirations of the people. Then the DPR also has a supervisory function on the implementation of Government Laws and Policies, in which the DPR has the right to provide recommendations to state officials or government officials that must be followed up by state officials or government officials. ${ }^{54}$ Thus, as representatives of the people, as well as its function as a supervisory institution, the House of Representatives can conduct checks and balances on policies carried out for the benefit of the government. It makes sense if the implementation of the principle of opportunity must go through the approval of the House of Representatives, which

Andi Hamzah, (et.al.), 2006, Loc.cit.

53 Andi Hamzah, Hukum Acara Pidana di Indonesia, Jakarta: Arikha Media Cipta, 1993, p. 50. See also RM Surachman, Mozaik Hukum I, Jakarta: Sumber Ilmu Jaya, 1996, p. 75.

54 See Article 72 in conjunction with Article 74 of Law Number 17 of 2014 on People's Consultative Assembly, House of Representatives, Regional Representatives Council, Regional Representatives Council (MD3 Law). 
represents the will and interests of the people, who will judge whether or not there is "public interest" in the case that will be dismissed. Although the reasons for "public interest" that are used to dismiss a case are made-up and irrational reasons, if the House of Representatives has given its approval, it is considered justifiable because it has gained the legitimacy and justification of all Indonesians through their representatives in the DPR.

\section{F. Conclusions}

Legislation policy on the application of the principle of opportunity in the Indonesian criminal justice system does not yet have a comprehensive and complete arrangement. There are no clear mechanisms and procedures for stopping the proceedings of criminal procedural law and have not reflected legal certainty due to formal requirements for dismissal of case. The term 'public interest' has no clear criteria, parameters, or limitations. The term can be interpreted variously depending on the points of view. The Attorney General especially can interpret subjectively the presence or absence of elements of public interest when a case dismissed because there is no obligation to follow suggestions or instructions from other state power bodies.

Based on a legal interpretation of the provisions of Article 35(c) of the Prosecutor's Law, it can be concluded grammatically that case dismissal for the public interest is carried out in the interests of the wider community voiced or represented by state institutions based on their assessment of the "public interest". The Attorney General, especially, does not need to follow advices and opinions of other state authority bodies. Then, it is more appropriate to formulate "for the public interest". Assembled with other state power bodies, grammatically the Attorney General is only asked to pay attention without the need to follow the advice given, or has no obligation at all to follow the advice and opinions of the bodies of state power related to the case. The consideration to do or not to carry out the dismissal is fully at the hand of the Attorney General. The systematic legal interpretation the meaning of "public interest" still remains biased and abstract because in the Indonesian laws and regulations, there is no criteria, parameters, or benchmarks. Based on historical legal interpretation, it can be concluded that dismissal of case for the public interest is not applied to small cases that can be resolved by the public prosecutor.

The implementation of the principle of opportunity under the Provisions of Article 35(c) of the Prosecutor's Law is contra-productive, inconsistent, and can be regarded as a form of discrimination against legal subjects. On the one hand, the state recognizes and affirms that everyone has the same position before the law. On the other hand, the state's recognition has been overlooked or excluded by the principle of opportunity. In addition, the application of the principle of opportunity based on the Provisions of Article 35(c) of the Prosecutor's Law can impose value and authority from the principle of equality before the law because it is contrary 
to the right of everyone to obtain fair legal recognition, guarantee, protection and certainty, and equal treatment before the law.

Thus, the implementation of the principle of opportunity based on the Provisions of Article 35(c) of the Prosecutor's Law is irrelevant to be applied in the Indonesian criminal justice system because it does not reflect legal certainty. The implementation of the principle of opportunity in the Indonesian criminal justice system has not regulated fully. It is also discriminatory because it ignores and excludes the principle of equality before the law.

\section{References}

\section{Books}

A.Z. Abidin, Bunga Rampai Hukum Pidana, Sejarah dan Perkembangan Asas Oportunitas di Indonesia, PT. Pradnya Paramita, Jakarta, 1983.

Ahmad Kosasih, HAM dalam Perspektif Islam, Salembah Diniyah, Jakarta, 2003.

Ahmad Rifai, Penemuan Hukum oleh Hakim dalam Perspektif Hukum Progresif, Sinar Grafika, Jakarta, 2010.

Andi Hamzah, (et.al.), Laporan Analisis dan Evaluasi Hukum Tentang Pelaksanaan Asas Oportunitas dalam Hukum Acara Pidana, BPHN, Jakarta, 2006.

Andi Hamzah, Hukum Acara Pidana di Indonesia, Arikha Media Cipta, Jakarta, 1993. Arief Budiman, Teori Negara: Negara Kekuasaan dan Ideologi, Gramedia Pustaka Utama, Jakarta, 1996.

Azhari, Negara Hukum Indonesia, Analisis Yuridis Normatif Tentang Unsur-Unsurnya, UI Press, Jakarta, 1995.

Bernard Arief Sidharta, Refleksi Tentang Struktur IImu Hukum: Sebuah Penelitian Tentang Fondasi Kefilsafatan dan Sifat Keilmuan IImu Hukum Sebagai Landasan Pengembangan IImu Hukum Nasional Indonesia, cetakan ke-2, Mandar Maju, Bandung, 2000.

Departemen Kehakiman Republik Indonesia, Pedoman Pelaksanaan Kitab Undangundang Hukum Acara Pidana, Cetakan ke-3, Yayasan Pengayoman, Jakarta, 1983.

Djoko Prakoso, Eksistensi Jaksa Ditengah-tengah Masyarakat, Ghalia Indonesia, Jakarta, 1985.

Franz Magnis Suseno, Etika Politik Prinsip-Prinsip Moral Dasar Kenegaraan Modern, Gramedia, Jakarta, 1987.

H.M.A. Kuffal, Penerapan KUHAP dalam Praktik Hukum, UMM Press, Malang, 2005.

lip D. Yahya, Mengadili Menteri Memeriksa Perwira Jaksa Agung Soeprapto dan Penegakan Hukum di Indonesia Periode 1950-1959, PT Gramedia Pustaka Utama, Jakarta, 2004.

J.S. Badudu dan Sutan Mohamad Zain, Kamus Umum Bahasa Indonesia, Pustaka Sinar Harapan, Jakarta, 1994. 
Johny Ibrahim, Teori \& Metodologi Penelitian Hukum Normatif, Bayumedia, Malang, 2011.

Luna, Erik and Marianne Wade (eds.), The Prosecutor in Transnational Perspective, Oxford University Press, Oxford, 2012.

M. Yahya Harahap, Pembahasan Permasalahan dan Penerapan KUHAP, Penyidikan dan Penuntutan, Edisi kedua, Sinar Grafika, Jakarta, 2003.

Mardjono Reksodiputro, Hak Asasi Manusia Dalam Sistem Peradilan Pidana, Pusat Pelayanan Keadilan dan Pengabdian Hukum, Jakarta, 1994.

Mien Rukmini, Perlindungan HAM melalui Asas Praduga Tidak Bersalah dan Asas Persamaan Kedudukan di hadapan Hukum Pada Peradilan Pidana Indonesia, PT. Alumni, Bandung, 2003.

Mohammad Taufik Makarao and Suhasril, Hukum Acara Pidana Dalam Teori dan Praktik, Ghalia Indonesia, Jakarta, 2004.

Ni'matul Huda and Imam Nasef, Penataan Demokrasi dan Pemilu di Indonesia Pasca Reformasi, Kencana, Jakarta, 2017.

R. Wirjono Prodjodikoro, Hukum Acara Pidana di Indonesia, Sumur Bandung, Bandung, 1990.

Ramdlon Naning, Cita dan Citra Hak Asasi Manusia di Indonesia, Lembaga Kriminologi Universitas Indonesia-Program Penunjang Bantuan Hukum Indonesia, Jakarta, 1983.

RM Surachman, Mozaik Hukum I, Sumber Ilmu Jaya, Jakarta, 1996.

Subekti and R. Tjitrosoedibjo, Kamus Hukum, Pradnya Paramita, Jakarta, 1978.

Sudikno Mertokusumo, Bab-bab Tentang Penemuan Hukum, PT. Citra Aditya Bakti, Bandung, 1993.

The Liang Gie, Pertumbuhan Pemerintah Daerah di Negara Republik Indonesia, Volume III, Gunung Agung, Jakarta, 1968.

\section{Other Documents}

A. Karim Nasution, "Kepentingan Umum Sebagai Dasar Penyampingan Perkara", this paper is presented at Symposium on Principle of Opportunity Issues, Ujung Pandang November 4-5, 1981.

Abdul Selamat Nazar, Penerapan Asas Equality Before The Law Dalam Tindak Pidana Korupsi (Studi Tentang Bentuk Penahanan Pada Sidang Pengadilan Tipikor), Jurnal Nestor Magister Hukum Universitas Tanjungpura, Vol. 2, No. 2, 2012.

Arin Karniasari, "Tinjauan Teoritis, Historis, Yuridis dan Praktis terhadap Wewenang Jaksa Agung dalam Mengesampingkan Perkara Demi Kepentingan Umum", a thesis in the Master Program of the Faculty of Law, Universitas Indonesia, 2012. Constitutional Court, Minutes of Case Session Number 29/PUU-XIV/2016.

Dhea Yudhista (ed.), "Keterangan ahli Tentang Konstitusionalitas Pasal 35 Huruf C Undang-Undang Republik Indonesia Nomor 16 Tahun 2004 Tentang Kejaksaan Republik Indonesia terhadap Undang-Undang Dasar Negara Republik Indonesia 
Tahun 1945", https://fh.umi.ac.id/keterangan-ahli-tentang-konstitusionalitas-pasal35-huruf-c-undang-undang-republik-indonesia-nomor-16-tahun-2004-tentangkejaksaan-republik-indonesia-terhadap-undang-undang-dasar-negera-republik-indon/.

Eka N.A.M Sihombing, "Mendorong Pembentukan Peraturan Daerah Tentang Bantuan Hukum Di Provinsi Sumatera Utara", Jurnal Rechtsvinding Media Pembinaan Hukum Nasional, Vol. 2, No. 1, 2013.

Jimly Asshidiqie, "Negara Hukum Indonesia", presented on 'General Lecture in the Inauguration of the Central Executive Board of the Alumni Association of Universitas Jayabaya', Jakarta, Januari 23, 2010.

Minutes of the Hearing Session III of DPR GR, the Joint Meeting of the whole commission to 11th, May 29, 1961.

Republika, "Hakim tersedu-sedu Bacakan Putusan Nenek minah", http://www. republika.co.id/berita/breaking-news/hukum/09/11/20/90390-hakim-tersedu-sedubacakan-putusan-nenek-minah.

Saladin Ayyubi, "Dituduh curi Buah Kakao 3 Biji Nenek Ditahan Rumah 3 Bulan", https://news.okezone.com/read/2009/11/20/340/277724/dituduh-curi-buah-kakao-3biji-nenek-ditahan-rumah-3-bulan.

Sjachran Basah, "Permasalahan Arti Kepentingan Umum", Pro Justitia - Faculty of Law Parahyangan University Magazine, June 1983.

Voa Indonesia, "Kasus Abraham Samad dan Bambang Widjojanto", http://www. voaindonesia.com/a/jagung-deponering-kasus-abraham-samad-dan-bambangwidjojanto--/3219269.html.

\section{Law Documents}

The 1945 Constitution of the Republic of Indonesia Law Number 8 of 1981 on Criminal Procedure Code.

Law Number 39 of 1999 on Human Rights.

Law Number 16 of 2004 on Attorney of the Republic of Indonesia.

Law Number 48 of 2009 on Judicial Power.

Law Number 17 of 2014 on People's Consultative Assembly, House of Representatives, Regional Representatives Council, and Regional House of Representatives. 